\title{
DO HUMANISMO RIDÍCULO: A CRÍTICA DA PERFECTIBILIDADE HUMANA EM PASCAL E LUTERO
}

\author{
Luiz Felipe Pondé* \\ lfponde@pucusp.br
}

RESUMO O texto tem três camadas. A primeira apresenta a construção semântica do conceito filosófico de "humanismo" a partir dos artiens medievais (século XIII), chegando ao seu clímax na Renascença, identificado com a obra de Pico de La Mirândola e sua mística da "suficiência e dignidade da natureza humana". A segunda camada do texto é a crítica que o reformador Lutero e o jansenista Pascal fazem ao "humanismo" e sua mística, concentrando essa crítica na idéia de que nada no comportamento humano sustenta um tal conceito, e que, portanto, se trata de uma abstração sem fundamento, e não de um fato empírico. Na terceira e última camada, analisam-se os desdobramentos desse embate, indicando que, possivelmente, os críticos cristãos do humanismo teriam acertado na sua dúvida com relação à viabilidade de um tal "culto ridículo da natureza humana".

Palavras-chave Humanismo; Perfectibilidade; Construção; AntiHumanismo; Pascal; Lutero; Renascença; Pico de La Mirândola; Natureza Humana

\footnotetext{
* Professor do Programa de Estudos Pós-Graduados em Ciências da Religião e do Departamento de Teologia da PUC-SP. Artigo recebido entre $1^{\circ}$ e 30 de abril de 2006 e aprovado entre $1^{\circ}$ e 31 de maio de 2006.
}

KRITERION, Belo Horizonte, $n^{\circ}$ 114, Dez/2006, p. 347-366. 
ABSTRACT The text has three levels. On the first level, we follow the semantic construction of the philosophical concept of "humanism", from the artiens in the 13 th Century up to Pico de La Mirandola and his mysticism of "human nature dignity and sufficiency" in the Renaissance. On the second level, we examine Luther's and Pascal's criticism of "humanism", showing that human behavior gives no empirical support for such abstract mysticism. Last but not least, on a third level, we argue that the Christian critics of humanism seemed to be right in doubting the viability of such "ridiculous worship of human nature".

Keywords Humanism; Perfectibility; Construction; Anti-Humanism; Pascal; Lutero; Renaissance; Pico de La Mirandola; Human Nature

\begin{abstract}
Instalei a construção e ela parece bem-sucedida. Por fora é visível apenas um buraco, mas na realidade ele não leva a parte alguma, depois de poucos passos já se bate em firme rocha natural. Não quero me gabar de ter executado deliberadamente essa artimanha, o buraco era muito mais o resto de uma das várias tentativas frustradas de construção, no final, porém, pareceu-me vantajoso deixá-lo destapado. Evidentemente, existem ardis que de tão finos liquidam a si mesmos, sei disso melhor que ninguém, e sem dúvida é temerário chamar a atenção, através do buraco, para a possibilidade de que aqui exista alguma coisa digna de ser investigada. (Kafka, 1998, p. 60 ; grifos meus.)
\end{abstract}

O termo "humanismo" é de largo uso entre nós. Podemos ouvi-lo desde as hostes empresárias - "por uma empresa mais humana!" - até em espaços supostamente mais críticos - "por uma sociedade mais humana!", significando, geralmente, uma sociedade menos "técnico-dependente" e centrada no "humano", isto é, "humano" aqui seria antes de tudo um "tipo ideal" regulador pseudoweberiano. A filosofia e sua história estão excluídas dessa discussão (que não passa de puro senso comum, ainda que possa se dar dentro dos muros da Academia), na medida em que a filosofia é apenas uma das demais atividades profissionais praticadas, e que dentro deste seu asfixiado espaço de ação, não se encontra a função de corrigir usos semânticos ou pragmáticos (a prática filosófica hoje não se caracteriza por nenhum exercício social de "consciência semântica"). Em outras palavras, nada teríamos a dizer, como filósofos profissionais, sobre o que os seres humanos entendem por "humanismo". Enquanto isso, somos todos, evidentemente, "humanistas". Como se rigor (a higiene pela qual nos recolhemos) e asfixia fossem atitudes 
noéticas gêmeas. Quando nos debruçamos sobre a história conceitual deste termo, percebemos que, se hoje ele é parte do jargão dos "recursos humanos" e da consultoria existencial, ele já foi objeto de violentos debates filosóficos e teológicos - aliás, uma das suas mais fundamentais raízes nasce precisamente no choque entre esses dois campos de saber.

O termo "humanista" não é uma evidência, pelo contrário, trata-se de um caso claro de instabilidade semântica e pragmática. Quando o utilizamos, o fazemos, normalmente, por aproximação e concessão. "Humanismo", "humanista", "anti-humanismo" remetem a controvérsias que nos levam ao período usualmente denominado de Renascença, ainda que, a rigor, não possamos afirmar simplesmente que os autores renascentistas usassem tais termos do modo que hoje nos é aparentemente evidente (ou mesmo que fizessem uso deles). Sua consistência filosófico-histórica ${ }^{1}$ é, antes de tudo, uma polêmica acerca da "natureza humana" - conceito em franco declínio em termos de estabilidade semântica e pragmática nas ciências humanas, foco de agressivas controvérsias entres os sócio-simpatizantes e bio-simpatizantes. Veremos que, precisamente, trata-se de uma discussão acerca da consistência da vontade humana, isto é, sua autonomia e validade. Se a abordagem de tal termo exige cuidados de uma arqueologia obsessiva do conceito, sua relação de implicação filosófico-histórica com o mito moderno de "Homem" salta aos olhos: o mito do "humano" (esse universal tardio, refugo da navalha nominalista) é uma construção a serviço de nossa "auto-imagem", isto é, o orgulho. Essa suspeita está na raiz da recusa da Reforma clássica e do jansenismo (esse calvinismo manqué) da "dogmática humanista".

Acredito que as críticas do reformador Lutero e do jansenista Pascal ao "humanismo" nascente são úteis para um diálogo com essa construção. O vocabulário de partida desses autores é a herança agostiniana da teologia da graça e os embates internos ao cristianismo "humanista" posterior. O "desencaixe" da filosofia da sua condição de "serva" da teologia a partir da Paris do século XIII é uma outra referência importante. O Renascimento (a discussão em Pico de La Mirândola especificamente) é um terceiro marco essencial desse processo. Minha intenção aqui não é, evidentemente, abarcar essa discussão na totalidade, mas simplesmente tentar compreender o foco da crítica luterana e pascaliana ao mito do "humano" suficiente.

1 F. J. Niethammer, em 1808, utiliza o termo "Humanismus" como uma tendência a destacar a importância do estudo das línguas. Segundo Campana (1946, p. 60-73), em 1538 encontramos usos como "Umanista". Mas, se nos libertarmos do termo "em si", encontraremos usos que legitimam o entendimento de "humanismo" - e seus similares - como um "tipo ideal de auto-imagem". 


\title{
Da construção
}

\begin{abstract}
Inversamente, compreende-se que um esforço de conhecimento do homem que se apóie na experiência humana e nos dados da pesquisa filosófica não encontre, no seu esforço de elucidação, nada que venha confirmar esta doutrina da "queda" do homem. Se a filosofia não tem o papel de se opor a teologia ou de combatê-la, é seu papel, entretanto, afirmar a distinção radical entre a questão filosófica da perfeição do homem e os pressupostos teológicos acerca da correção e da queda de nossa natureza. (Faye, 1998, p. 24)
\end{abstract}

A discussão medieval (século XIII) e renascentista, tal como apresenta Faye na sua obra sobre a perfeição possível da natureza humana, é especialmente elucidativa dessa questão na medida em que opõe duas idéias que supostamente implicam-se: a afirmação dogmática da teologia a respeito da corrupção inevitável da natureza humana devido à queda, por um lado, e por outro, à afirmação de que a filosofia, a partir dos instrumentos que lhe são característicos (pesquisa elucidativa e experiência humana, segundo Faye), não encontra nenhum dado empírico (acrescento eu) que negue necessariamente a possibilidade da perfectibilidade humana. Segundo Faye, a questão filosófica acerca da perfeição possível não encontra na apreciação teológica nenhuma consistência deslegitimadora a priori. Ao libertar-se da negatividade teológica, a filosofia do homem torna-se capaz de respirar a possibilidade da indefinição redentora: o verdadeiro ganho aqui não é da ordem de um empirismo positivo (a negação do a priori teológico não implica a afirmação de nenhum a priori que lhe seja simetricamente oposto), mas apenas da ordem de um ideal. Evidentemente que, se não há evidências definitivas sobre a queda, também não há evidências definitivas sobre a perfectibilidade humana. A liberação "descoberta" aqui é da ordem da ausência de predeterminação sobrenatural. O conceito de perfectibilidade, entretanto, necessita, parece-me, de uma idéia de processo que implica a auto-superação de condições previamente definidas como parâmetro a legitimar o ganho em perfeição: da caverna ao avião, ou do sacrifício humano à democracia do consumo feliz, por exemplo. Diria que, antes de tudo, o "verdadeiro avanço" da filosofia tardo-medieval e renascentista nesse caso se dá com relação à tutela teológica falsamente necessária, e não com relação a um campo de evidências que apresentaria uma legitimidade livre de dogmas ou mitos. A indefinição da natureza humana (supostamente) sustentada na pesquisa elucidativa e na experiência humana deságua numa construção e não numa evidência simetricamente oposta ao obscuro mito da queda. Vejamos alguns instantes dessa construção.

O "desencaixe" referido acima tem como referência fundamental o processo que vai dos artiens de Siger de Brabant no século XIII parisiense a 
autores como Pico de La Mirândola no século XV ou Charles de Bovelles no início do XVI (e aos "humanistas" renascentistas em geral): trata-se de um elogio à dignidade da filosofia ("humanizada") em si.

Há entretanto algo que caracteriza propriamente os filósofos artiens do séc. XIII: seu ascetismo e sua valorização absolutamente exclusiva da vida do intelecto (...). A este respeito, a corrente filosófica que vai se manifestar na França no séc. XVI trará uma concepção mais completa da perfeição do homem, considerando prioritariamente o conjunto de virtualidades de sua natureza, de uma só vez corporal e espiritual. (Cf. Faye, 1998, p. 27.)

Essa idéia de "virtualidades da natureza humana" será central, assim como o processo de compreensão do intelecto como uma faculdade que não demanda conteúdos sobrenaturais para sua realização plena, virtude maior para os artiens. A idéia de dignidade da vida filosófica pura encontra aí seu locus conceitual: dignidade descreve uma virtude, não uma evidência. A defesa dos artiens parisienses do intelecto per se abrirá espaço para "uma concepção mais completa da perfeição do homem" no Renascimento, segundo Faye. Vemos que é antes de tudo o parti pris da imperfeição teologicamente predeterminada que está no foco do "desencaixe". Como parte desse movimento, a idéia de suficiência (autonomia) do conjunto dessas "virtualidades naturais do Homem" lança suas bases. O "pessimismo" da Reforma atacará precisamente essa idéia de exclusão da eficácia transcendente restrita. "Concepção mais completa da perfeição" se refere exatamente às "virtualidades" corporais e espirituais em questão. Vemos, portanto, que o que normalmente chamamos de "humanismo" renascentista é um termo equívoco (isto é, semanticamente polissêmico, no mínimo): neste caso refere-se a uma exclusão da teologia da queda como hipótese determinante na antropologia filosófica, e por sua vez afirma, idealmente, uma autonomia desse conjunto de "virtualidades". Não me parece que possamos opor uma mitologia "javista" a uma empiria "humanista". ${ }^{2} \mathrm{De}$ um ponto de vista estritamente neopragmático, diria que se trata de uma mera redescrição supostamente autovalorativa. Os agostinianos modernos veriam aqui uma sofisticadíssima elaboração da terceira concupiscência, o orgulho. O foco da discussão é a perfeição e a dignidade postuladas, não uma descrição justificada. Trata-se de um "enunciado" moral e não conceitual-empírico. Se o mito teológico é um fantasma, o "humano" também o é.

2 Freudianamente, poderíamos dizer que aqui parece ser precisamente um caso no qual o paciente - "os homens e mulheres" - re-significa sua auto-imagem, optando por uma versão menos autodepreciadora. Mas trata-se apenas de uma metáfora. 
É por isso que eu propus renunciar um termo anacrônico e problemático para focar a pesquisa na terminologia própria da época, estudando a maneira como a dignitas hominis foi historicamente pensada (...).

Se abstrairmos de fato cada autor particularmente para considerar a questão da dignidade do homem de maneira geral, percebemos que esta noção (...) obedece sempre historicamente o mesmo motivo maior, aquele do livre-arbítrio. Não há nada aí de propriamente renascentista. (Cf. Faye, 1998, p. 31)

Vemos que o topos da dignitas hominis é na realidade a discussão acerca do livre-arbítrio. Os medievais - Duns Scotus, Bernard de Clairvaux, Richard de Saint Victor, entre outros - já pensavam essa dignidade humana, mas ela estava necessariamente condicionada pela capax Dei do Homem, isto é, sobrenaturalmente determinada. A diferença renascentista em termos teoréticos (morais e ontológicos) para com os medievais reside na exclusão da temática da corrupção do livre-arbítrio, bem exemplificada pelo tormento da De miseria humanae conditionis (Lotário, mais tarde Papa Inocêncio III) recusada por autores como Pico, entre outros. ${ }^{3}$ Esta é a característica essencial da mitologia "humanista": a identificação do virtual livre-arbítrio com a real possibilidade humana de ser livre de qualquer disfunção moral $a$ priori. Evidentemente que temos aqui um argumento teológico em jogo (nos medievais), mas não me parece tão evidente que o abandono do vocabulário explicitamente teológico resolva a questão a favor da mitologia "humanista". Penso que uma apreciação empírica pode não necessariamente justificar a posição renascentista naive.

$\mathrm{O}$ argumento renascentista ${ }^{4}$ não é (ou, pelo menos, não evidentemente) que haja uma perfeição a priori da natureza humana - isto é, de sua dignidade enquanto ser capaz de um livre-arbítrio suficiente -, mas sim que existe uma potencialidade infinita (virtualidade) não predeterminada por qualquer incapacidade necessária restritiva. Essa restrição era o argumento da corrupção.

A verdadeira distinção consiste, aliás, no fato dele não ter qualquer propriedade fixa, mas ter o poder de partilhar de todas as propriedades de todos os outros seres, de acordo com sua própria escolha livre. (Cf. Kristeller, 1956, p. 218)

Segundo Kristeller é precisamente esta emancipação com relação à hierarquia medieval dos seres que liberta o Homem da restrição (fixadora de

3 Cf. FAYE, 1998, p. 32.

4 Toda vez que mencionar a posição renascentista na seqüência, refiro-me especificamente ao argumento da indefinição humana, tal como é defendido por Pico de La Mirândola. 
propriedades) presente na idéia de um pecado condicionante. Ouçamos o próprio Pico:

3. (...). Ele, portanto, tomou o homem como uma criatura de natureza indeterminada (...) A natureza de todas as outras coisas é limitada e restrita às fronteiras das leis prescritas por Nós. Vós, restrito por nenhum limite, de acordo com vosso próprio livre-arbítrio, (...) ordenará (sic) por si mesmo os limites de vossa natureza. (...).

4. (...). Para ele é garantido ter o que quer que ele escolha, ser o que quer que ele deseje. (Cf. Mirândola, 1956, 224-225)

A idéia de indefinição na realidade vem sustentar a idéia de potência infinita sem condições. Percebe-se na argumentação da Oração uma marcada tendência a negar a própria noção de condição humana (no caso específico, o condicionamento restritivo teológico): sua condição mínima é ser livre para qualquer coisa, ele poderá degenerar em besta ou alçar vôos aos anjos, logo, seu livre-arbítrio é a instância determinadora de seus possíveis condicionamentos vividos. Sua escolha é causa. É evidente que a discussão e o vocabulário de Pico são de viés teológico. Ele descreve uma benção recebida pelo Homem, benção esta que se caracteriza pelo livre-arbítrio indefinido. A filosofia "humanista" de Pico é "teologia" sem restrição condicionante. ${ }^{5}$ Nesse sentido, o "desencaixe" ao qual fazia referência acima se revela mais uma vez como exclusão da condição corrompida do livre-arbítrio e da eficácia estrita do Transcendente com relação ao "humano". Trata-se de uma controvérsia interna a concepção divinizante do Homem, mas que rompe com o infeliz argumento da miséria. Essa hipótese da indefinição é o núcleo da dignitas hominis, core da idéia de suficiência da natureza humana que se realiza plenamente na produção da cultura.

A idéia de indefinição (apresentada na Oração) será fundamental para entendermos a passagem de uma concepção puramente histórica da posição "humanista" no Renascimento para uma discussão filosófica. Todavia, a definição estritamente histórica, isto é, "humanismo" como erudição clássica que recupera a tradição greco-romana não cristã, não deixará de ter um importante papel na construção ${ }^{6}$ da mística do "humano": indefinição, dignidade, nobreza, natureza-cultura e suficiência.

5 Não quero especificamente invalidar a posição de Faye quanto à libertação da filosofia com relação à teologia - nem posso me dedicar a essa questão aqui -, mas apenas marcar o fato de que essa libertação, pelo menos no que se refere à obra de Pico - e seu conceito de indefinição me parece central na construção do "mito humanista" na medida em que afirma o livre-arbítrio e deduz daí sua dignidade nobre -, se dá num horizonte religioso, restringindo apenas o foco a uma oração feita à dignidade humana e não Àquele que condicionaria eficazmente o livre-arbítrio humano.

6 Como afirmam Kristeller e Randall: “Embora 'as Humanidades' seja meramente outro nome para esses estudos específicos, a escolha do termo implica uma demanda muito característica do ideal cultural 
Qual é exatamente a noção que operou a passagem do sentido histórico (clássico) ao sentido filosófico, que conduziu dos humanistas historicamente determinados ao humanismo constituído em categoria filosófica?

(...) O humanismo é "o que se poderia chamar de misticismo da nobreza (de caráter) humana" (...) "é exatamente o mesmo misticismo da grandeza humana que sustenta o homem da Renascença e o humanista". (...) "Pode-se definir o humanismo como uma ética da nobreza humana". (Cf. Gouhier, 1987, p. 17)

Citando Augustin Renaudet, ${ }^{7}$ Gouhier elenca definições que se tocam precisamente no caráter ideal da dignidade humanista. Sendo uma ética, se por alguma razão o argumento teológico da corrupção tiver consistência, a ética revelar-se-á fantasmática. Se não há qualquer restrição empírica para se romper com a hipótese sombria da Queda, também não há qualquer restrição empírica para se suspeitar da fantasmática da dignidade humanista. É a suspeita agostiniana quanto ao impulso intelectual que estaria na base do "humanismo" (de efeito claramente crítico): a ética fantasma serve a mentira antropológica acerca do próprio Homem, alimentando a disfunção (o orgulho estrutural, o amor pelo nada da criatura) que ela mesma denega ao excluir o argumento sombrio. Mas, antes de nos lançarmos à negatividade da construção, acompanhemos esta última, e longa citação, que, acredito, resume de modo preciso o core do argumento "humanista" e que também ilumina o foco da crítica anti-humanista agostiniana moderna.

(...) à idéia confusa de "grandeza", propõe-se substituir a idéia distinta de "suficiência", permitindo reconhecer o humanismo em três caracteres precisos:

$1^{\circ}$ Humanismo significa uma certa suficiência do homem (...) o homem pode qualquer coisa, pelas únicas forças que o fazem homem, razão e vontade especificamente.

$2^{\circ} \mathrm{O}$ que significa: pelas únicas forças de sua natureza. Não é de modo algum por acaso que a noção de natureza sempre esteve ligada a de humanismo (...). A suficiência que o humanismo reconhece é, de fato, aquela da natureza. Ora, para que ela é suficiente? Trata-se da natureza poder realizar-se: sua suficiência significa então que, dentro de certos limites, ao menos, a natureza é capaz de reconhecer e atingir o bem; dito de outra forma, ela implica uma relativa bondade da natureza.

e educacional dos Humanistas: o cultivo dos clássicos ou 'as Humanidades' é justificado porque ele serve para educar e desenvolver um desejável tipo de ser humano. Pois os clássicos representam o mais alto nível da realização humana e deveria ser, assim, de preocupação essencial para todo homem." CASSIRER; KRISTELLER; RANDALL JR., 1956, p. 4. O locus da cultura (como topos que define o modo de ser natural do Homem) aqui é essencial na medida em que a tendência histórica será a de definir o Homem como um animal da cultura em oposição a de um animal sobrenatural. A relação de identidade entre ser um animal da natureza estritamente e ser uma animal da cultura é de grande valor, mas infelizmente não posso me deter especificamente nessa fronteira conceitual neste momento.

7 Cf. RENAUDET, 1945. 
$3^{\circ}$ Esta natureza do homem tem como particularidade de se realizar na e pela cultura. Não é de modo algum por acaso que a noção de cultura sempre esteve ligada a de humanismo: vemos isso bem hoje quando se fala de "humanismo moderno" ou de "humanismo técnico". (...)

Suficiência, natureza, cultura são três termos complementares; ${ }^{8}(\ldots)$ lá onde eles não se encontrarem, deve-se falar de anti-humanismo. (Cf. Gouhier, 1987, p. 20-21)

A relação com a cultura é, portanto, posta já na raiz do culto da dignidade humana a priori. O caráter naive é evidente: não seria a história um desfile de horrores? O que há de determinantemente belo na "cultura"? Facilmente podese cair em denial com relação a essa razoável evidência, basta alimentarmos aquilo que jamais deve ser ferido (nossa auto-estima ontológica ou soberba), diriam os reformadores modernos. Creio que essa atmosfera mítica permanece entre nós, apenas recusamos sua consciência pragmática e semântica.

Esta glorificação do homem era um dos temas favoritos da literatura da jovem Renascença. Durante o séc. XVI isso produziu uma reação violenta. A ênfase na total depravação encontrada na teologia da primeira Reforma protestante pode ter sido uma resposta ao exagerado louvor ao homem comum na literatura humanística do tempo deles. (Cf. Cassirer; Kristeller; Randall Jr., 1956, p. 19)

Na continuação deste trecho, Cassirer, Kristeller e Randall afirmam que o que esta por detrás da violenta reação contra os exageros das orações humanistas é a concepção agostiniana de Homem. Eles o fazem referindo-se a Montaigne, esse renascentista pouco "humanista". Todavia, segundo nossos scholars, o que caracteriza a abordagem crítica de Montaigne é pensar a partir dessa concepção agostiniana só que "desteologizada" ou "humanizada", isto é, sem referências às crenças dogmáticas (redundância?). Interessante lembrar que com Montaigne estamos em solo cético. A concepção agostiniana sem seu componente teológico "redentor" deságua necessariamente em crítica cética e pessimismo antropológico agressivo, traços de uma atitude noética que por ser saturada de realismo (no sentido oposto a idealismo), aparentemente asfixia. Argumentos de efeito cético usualmente revelam-se poderosos em termos empíricos.

\section{Da negação}

A verdade não é primeira, ela é da ordem da desilusão; ela é sempre uma desmistificação que supõe a mistificação que a funda e que ela desnuda. Toda sociedade sobrevive

8 Cf. nota 7. Seria exatamente esse terceiro ponto que falaria da "continuidade" da natureza manifestandose ao longo da história da cultura. Os clássicos representariam este período anterior como uma infeliz incursão de um discurso que feria e negava a possibilidade de autonomia da natureza humana. 
pela auto-mistificação de seu funcionamento, a fim de assegurar sua perenidade e pelo desejo de mascarar seu caráter extraordinariamente auto-destrutível. (Cf. Quignard, 1996, p. 65)

A descrição do processo de aquisição da "verdade" deste jansenista contemporâneo (Quignard), comentando um outro jansenista (Esprit), este do século XVII, carrega nos tons típicos da reação agostiniana ao culto da suficiência humana da Renascença: desilusão como transcendental epistêmico. Qual ilusão específica? A construção vaidosa. As raízes dessa reação, no campo da antropologia filosófico-teológica, estão na reflexão de Agostinho sobre o livre-arbítrio. Não se trata de negar a possibilidade de se usar o termo "dignidade" para o ser humano em qualquer que seja a situação, trata-se sim de questionar a consistência da oração ao livre-arbítrio, ou seja, o culto da autonomia moral auto-evidente. O resto conceitual filosófico dessa crítica é a idéia de uma disfunção cognitiva e volitiva no Homem.

Que tens que não tenhais recebido? E se foi recebido, por que te glorificas como se não tiveste recebido como dom? Isto é: Por que te glorificar, como se tiveste recebido de ti mesmo um dom que, se não o tiveste recebido, tu não poderias possuir por ti mesmo? (...). Mas vale possuir menos do que pedimos a Deus do que possuir mais do que atribuímos a si mesmo. (Cf. Sto. Agostinho, 1994, p. 50-51, 10)

E mais:

Mas para ir em direção ao pecado, o livre-arbítrio é suficiente, com o que ele estragou a si mesmo; ao contrário, para retornar à justiça ele necessita de um remédio pois ele está doente. (...). Muito pelo contrário, ao defender a natureza como se ela fosse suficiente a si mesma para ser justa, assumindo que só ela intervém, é contra a graça do Cristo, pela qual nós somos justificados, que ele se eleva de uma forma manifesta (...). Isso, um espírito orgulhoso não pode compreender. (Cf. Sto Agostinho, 1994, p. 290-295, XXIII/XXV)

Agostinho ataca a idéia de suficiência defendida por Pelágio por considerála orgulho. E mais, o mesmo orgulho é levado à categoria de transcendental epistêmico negativo que inviabiliza a compreensão da sua crítica: exemplo da submissão do espírito (intelecto) à vontade orgulhosa. Ainda que o termo seja anacrônico - já o é para o Renascimento em si! - a suficiência pelagiana é uma idéia de natureza humana que em muito se aproxima da oração humanista. Agostinho negará a suficiência afirmando a estrita necessidade da graça eficaz e contingente (não está submetida à economia racional dos méritos humanos) para que o livre-arbítrio escape do peso da gravidade do pecado. Ao longo da 
argumentação, ${ }^{9}$ Agostinho descreve as misérias empíricas humanas como prova de que a hipótese da queda explica melhor a condição humana do que a tentativa vã - ainda que, reconhece Agostinho, em certa medida justificada pela revolta de Pelágio em ver o lachismo moral dos cristãos que responsabilizava o pecado pelo estado lastimável da condição humana, numa espécie de maniqueísmo perverso - de sustentar uma possível autonomia moral. Agostinho opõe a realidade de uma condição empiricamente dada (a natureza humana parece atolada numa repetição monótona de atos condicionados pelo amor à criatura, a começar pelo amor por si mesmo) à possibilidade de um descondicionamento gerado pelo livre-arbítrio. Agostinho vê esse condicionamento como a corrupção teologicamente descrita pelo pecado. Pelágio, por sua vez, aposta na viabilidade desta condição ser mera retórica existencial (em ternos contemporâneos) para preguiça moral. Agostinho reconhece o valor da luta contra a preguiça, mas chama a atenção para não tentarmos resolver essa preguiça falsamente: a solução pelagiana é uma chamada ao orgulho humano "estoicizante", ao reconhecimento de uma dignidade da liberdade humana, isto é, a troca da retórica da desculpabilização pela retórica do orgulho construtivo da personalidade (obviamente que, de novo, num vocabulário contemporâneo). Este núcleo de temas (falsa suficiência, erro, vaidade, ${ }^{10}$ etc.) será retomado pela Reforma e pelo jansenismo em geral, ainda que guardando diferenças importantes em se tratando de Lutero e Pascal.

Agora, este livro deveria ter um título (para indicar) que foi escrito contra o livrearbítrio. Pois o livro inteiro tende a mostrar que as opiniões, planos e empreitadas dos homens são todos em vão e estéreis, e que eles sempre têm uma solução diferente do que nós desejamos e propomos. Assim sendo, Salomão nos ensinaria a esperar em confiança e deixar que Deus sozinho faça tudo, acima e contra e sem nosso conhecimento e opinião. (Cf. Lutero, 2002, p. 68; grifos meus)

Para Lutero, o Eclesiastes ${ }^{11}$ não deve ser entendido como uma desqualificação da Criação em si, mas sim uma crítica à idéia do Homem como causa racional e moral. O reformador vê como sabedoria o reconhecimento

9 Outras obras que fazem parte dos dois volumes que compõem La Crise Palegienne do Institut d'Études Agustiniennes de Paris: De Perfectione lustitiae Hominis, De gratia christi et De peccato originali libri II e De natura et origine animae libri $I V$.

10 Ë de suma importância ter em mente o cruzamento dos sentidos de efêmero, vão e vaidoso, contidos nessa discussão do orgulho, principalmente quando vemos que Lutero dá tanto valor ao Eclesiastes como sendo o livro por excelência escrito contra a ilusão de autonomia do livre-arbítrio.

11 Muitas vezes o Quohelet é descrito como o cético da Bíblia hebraica, ou seja, o livro da sabedoria contra as articulações supostamente sábias do Homem; no judaísmo, é lido normalmente em momentos de alegria (como após a colheita) a fim de lembrar ao Homem técnico que não deve tomar-se como causa dos seus aparentes sucessos; cf. GUTTMANN, 2003. 
de que Deus não leva em conta nosso saber para conduzir sua Criação. Percebemos aqui um modo duro de exclusão do que poderíamos denominar a dinâmica do humano, mas o core dessa exclusão é o livre-arbítrio, pois para Lutero, como veremos na seqüência, a situação humana é tal como descreve Agostinho. Esse prefácio foi escrito na mesma época (1524) em que Erasmus de Rotterdam preparava De libero arbitrium (publicado na Basiléia) e contra quem Lutero escreverá sua Da vontade cativa. Nas palavras sintéticas de um comentador, que julgo bem precisas na definição da postura luterana:

A condenação final de Erasmo, da parte de Lutero, é feita com as palavras iniciais do livro. As formulações são cortantes, têm tom de juízo final e caracterizam a diversidade de pressupostos de ambos. Do lado de Erasmo há suma inteligência que, no entanto, foge de toda decisão. Do lado de Lutero há a verdade insofismável do Deus santo e maravilhoso, pelo qual a razão e a vontade se deixam cativar em obediência e humildade. (Cf. Dreher, 1993, p. 16)

Sofisma: a posição que cultua a autonomia funcional da vontade e da razão é vista como jogos inteligentes de palavras, por isso sem valor para Deus (ele age contra e acima desses jogos), mas que são inconsistentes no sentido decisório, logo, nada valem. Seu valor é apenas a repetição do amor por si mesmo, orgulho da criatura. Essa percepção de que a defesa da autonomia humana é retórica vazia contra a empiria que nega a consistência dessa retórica percorre todo o agostinismo lido pela Reforma e pelo jansenismo. ${ }^{12}$ No Prefácio a Carta aos Romanos (versão de 1546), Lutero aprofunda seu ceticismo:

Portanto, todos os homens são chamados mentirosos no Salmo 116 (:11) porque ninguém guarda ou pode guardar a lei de Deus nas profundezas do coração. Pois todo mundo encontra em si mesmo desprazer no que é bom e prazer no que é mau. Se, então, não há prazer desejante no bem, o íntimo do coração não está estabelecido na lei de Deus. (...)

Acostume-se, então, com esta linguagem, que fazer as obras da lei e realizar a lei são duas coisas bem diferentes. A obra da lei é tudo que se faz ou se pode fazer, com relação a guardar a lei a partir do seu próprio livre-arbítrio e por seus próprios poderes. Mas uma vez que em meio a estas obras e ao longo delas permanece no coração um desprazer com a lei (...), estas obras são todas desperdiçadas e não têm nenhum valor. (...) Portanto, você pode ver que (...) os sofistas praticam o engano quando ensinam aos homens a se prepararem por si mesmos para a graça por meio das obras. Como pode um homem preparar a si mesmo para o bem por meio das obras, se ele faz boas

12 Como confirmação deste viés empiricista (há mais realidade na dúvida cética não humanista do que na defesa do humanismo) dentro da tradição scholar agostiniana, cf. SELLIER, 1995. 
obras unicamente com aversão e má vontade no seu coração? Como agradará a Deus uma obra se ela procede de um coração relutante e resistente? (...)

Fé não é a noção e nem o sonho humano que algumas pessoas chamam fé. (...) Isto se deve ao fato que quando eles ouvem o evangelho, eles se ocupam e por meio de seus próprios poderes criam uma idéia em seus corações que diz "eu creio"; eles assumem isso como sendo a verdadeira fé. Mas isso é ilusão e uma idéia que nunca toca as profundezas do coração, nada provém dele, e nenhum aperfeiçoamento se segue daí. (Cf. Lutero, 2002, p. 90, 92 e 94)

Nesta longa citação, na qual Lutero retoma a clássica crítica paulina ao behaviorismo das obras, ${ }^{13}$ percebe-se um encadeamento de argumentos que vai da recusa da execução vaidosa e exteriorizante da vontade de Deus (a Lei) à definição do caráter essencialmente invisivel desta Lei. Se lembrarmos que a Lei no judaísmo é a manifestação da vontade de Deus, e que não há teologia ontológica a rigor no judaísmo bíblico mas apenas teologia moral - monoteísmo ético ${ }^{14}$-, lembraremos que a discussão luterana toca em profundidade o que poderia ser o princípio de qualquer relação entre o Homem e Deus. Segue-se daí que não há relação entre o Homem e Deus sem que este tome a iniciativa - talvez aqui esteja uma das razões dos católicos acusarem Lutero de "hebraização" do cristianismo, por tornar Deus "excessivamente" transcendente. O exílio ontológico é representado pela inconsistência moral estrutural e não meramente conjuntural (assumindo a condição caída como estrutura). Segundo Lutero, o coração humano não é capaz de sentir prazer verdadeiro na busca de realizar a vontade de Deus - logo, não é capaz de realizar a ética de Deus, a única dimensão do Ser divino que conhecemos - pois este coração está perdido na retórica gestual, isto é, na mímica muda. Mais adiante, Lutero passa do abismo que rasga o humano - sua fratura interna entre retórica gestual do visível e sua inconsistência moral profunda - ao abismo ontológico entre natureza e sobrenatural: aquilo que psicologicamente (termo meu) entendemos quando produzimos enunciados como "creio" não é a realidade da fé verdadeira. O coração humano, locus da vontade desgarrada de Deus, campo de um hedonismo da criatura, é incapaz de produzir um salto de consistência moral - logo, ontológica, em se tratando de judaísmo ou cristianismo - diferencial: a verdadeira fé, assim como o estar em sintonia com a vontade de Deus, é fruto de uma causa que não tem lugar na dinâmica natural

13 Essa crítica era e é parte do próprio judaísmo, assim sendo, Paulo aqui aparece como um integrante dos críticos judeus desta característica legalista que o filósofo judeu Abraham loshua Heschel chama de behaviorismo religioso, isto é, ocupar-se com a realização exterior da Lei a fim de ganhar reconhecimento da sua condição de judeu correto sem consistência interior (sem espírito); cf. HESCHEL, 1999.

14 Cf. REHFELD, 2003. 
humana. Percebe-se que Lutero está criticando a idéia de que possa existir uma suficiência do sistema ético humano. Qualquer que seja a suficiência humana, será unicamente a da monotonia do pecado. Não há "humanismo" aqui, mas sim uma suspeita profunda de que o "humanismo" da dignidade natural humana - a exclusão do Transcendente estrito - nada seja além do que parte do gestual que desenha a visibilidade de uma dinâmica em queda. Sendo a queda uma queda na pureza infeliz da criatura, e sendo esta devorada ontologicamente pelo nada, é natural que Lutero considere um texto que fala das nuvens de nadas (Eclesiastes) como sabedoria profunda acerca da ilusão orgulhosa humanista. No comentário a Gálatas, Lutero resume sua crítica: "Tudo que está na nossa vontade é mal, tudo que está na nossa inteligência é erro. É por isso que no que se refere às coisas divinas, o homem não tem nada além do que puras trevas, erros, malícia, perversidade da vontade e da inteligência." (Cf. Lutero, 1958, p. 186)

Há um efeito de ampliação por precisão do alcance da miséria aqui: mergulhado na condição denegada pela oração humanista, o Homem aos olhos de Lutero é um sonâmbulo. Trata-se de um discurso que teologicamente fala do pecado, e que filosoficamente ilumina a condição humana com suspeitas de disfunção ontológica. Argumentos céticos, quando não estão a serviço de uma retórica puramente formal e cínica, são usualmente sombrios para as técnicas da vaidade. Karl Barth, grande teólogo protestante do século XX, define assim a antropologia reformada: "A perversão do pecado se produz no fundo e no centro da existência humana, no coração humano; e o estado de perversão pecaminosa que daí resulta se estende à totalidade de sua maneira de ser sem exceção de nenhuma de suas determinações." (Cf. Barth. Dogmatique IV, Cahier, p. 58)

As palavras de Barth apontam para a mesma ampliação da temática luterana: trata-se de uma antropologia crítica de apelo empírico, fruto da aplicação filosófica de uma dogmática teológica. A perfectibilidade do humano, preparada pelo "desencaixe" referido acima, mesmo tendo excluído pragmaticamente o vocabulário teológico, terá que enfrentar seu resto filosófico.

Pascal ${ }^{15}$ não era luterano, e escreveu parte de seus Écrits sur la grace ${ }^{16}$ contra a Reforma. Todavia, as relações entre o jansenismo e a Reforma

15 Já tratei detidamente da antropologia filosófica de Pascal em dois momentos, O Homem Insuficiente, 2001, e Conhecimento na Desgraça, 2004, ambos pela Edusp, por isso não vou repetir o que digo lá. Minha intenção é simplesmente retomar alguns momentos pontuais que iluminem a falas suficiência da oração humanista.

16 Cf. PASCAL, 1991. 
(Lutero e Calvino) permanecem um campo de estudo a ser enfrentado. Talvez as contínuas acusações por parte do molinismo jesuíta de protestantismo com relação à interpretação jansenista de Agostinho não sejam totalmente infundadas. ${ }^{17}$ Entretanto, meu interesse aqui não são as particularidades que distanciam Pascal de Lutero - isto é, a crítica pascaliana com relação à afirmação de impermeabilidade à graça eficaz que segundo ele haveria nos erros luteranos e calvinistas, contra sua posição (de Pascal) que o Homem permanece permeável à graça eficaz, mas que ele jamais é causa eficiente e suficiente da ação dessa graça -, mas a crítica que ambos fazem à oração humanista, e nesse sentido, na medida em que a causa da relação possível entre Homem e Deus é sempre não humana, e que por definição o homem é disfuncional moralmente quando não sob ação de Deus. Essa posição implica que qualquer idéia de perfectibilidade humana possível ou é divina, ou é erro e desgraça revivida. O "desencaixe" antroponômico seria nesse sentido um erro evidente: o homem pelo homem é sempre miserável pois sua condição é a de um animal circular.

(...) ao considerá-las nos seus efeitos, se podem identificar as causas, as primeiras sendo as causas meritórias das segundas, e as segundas as causas finais das primeiras; mas ao considerá-las todas em comum, não há nenhuma causa além da vontade divina (...). (Cf. Pascal, 1991, p. 658)

Neste pequeno trecho temos um exemplo da argumentação pascaliana que define a causa ética como sendo Deus, ainda que aparentemente não de modo evidente. Na localidade da teia causal ética parece haver uma causa outra que não a graça eficaz, mas quando a perspectiva transcende $\mathrm{o}$ provincianismo cognitivo, percebe-se que esta causa é sempre secundária. ${ }^{18} \mathrm{~A}$ argumentação pascaliana é mais marcadamente filosófica - no sentido de ter maior autonomia em se tratando de vocabulários de raiz não proximamente teológica (Revelação). Todavia, seguindo o próprio Pascal na citação acima, também podemos aplicar a percepção epistêmica diferencial entre um olhar local e uma ampliação da visão dos argumentos-causas que sustentam a teia conceitual geral, e aí perceberemos que seu pensamento é essencialmente religioso ${ }^{19}$ - assim como os de Lutero. Citaremos três conceitos em particular (que não estão diretamente relacionados à controvérsia moral-teológica)

17 Cf. MICHON, 1996.

18 Cf. PONDÉ. Conhecimento na desgraça.

19 Não vou me deter nessas raízes, mas elas são próximas ao agostinismo protestante; cf. PONDÉ. O homem insuficiente. 
como exemplo da crítica antropológica pascaliana à viabilidade da oração $d a$ perfectibilidade: o par divertissement $x$ ennui (divertimento $\mathrm{x}$ angústia/ tédio/aborrecimento), a faculdade da contingência, isto é, a imaginação e seus efeitos perversos, e a natureza disjuntiva humana devido à heterogeneidade das ordens constituintes do ser humano. Ao final da argumentação pascaliana, resta-nos um Homem disfuncional a priori, no qual a desqualificação da idéia de dignitas hominis rompe a fronteira de uma discussão meramente moral.

\title{
Angústia $^{20}$
}

\begin{abstract}
Nada é tão insuportável ao homem quanto estar em pleno repouso, sem paixões, sem negócios, sem divertimentos, sem atividades. Ele então sente seu nada, seu abandono, sua insuficiência, sua dependência, sua impotência, seu vazio. Imediatamente sairá do fundo de sua alma a angústia, o negrume, a tristeza, a aflição, o despeito, o desespero. (Cf. Pascal, La 622)
\end{abstract}

Nesse fragmento Pascal faz sua análise existencial do Homem. Seu argumento, na realidade, é que, quando não se movimenta (se diverte), o Homem necessariamente se afoga naquilo que, sendo sua essência estrutural, brota do seu coração. Pascal nega que o Homem possa existir, quando o movimento auto-alienante cessa, sem experimentar angústia, desespero, tristeza. $\mathrm{O}$ foco da sua análise parece desviar-se de uma argumentação eminentemente moral para um cenário psicológico profundo. O gestual retórico da perfectibilidade seria, nesse sentido, um modo de desviar-se da agonia essencial, negando o condicionamento teológico, mas permanecendo presa da inevitável angústia ontológica. Seria possível negar essa autopercepção negativa profunda, apontada por Pascal, e que nos remete à sensação de insustentabilidade estrutural em termos precisamente empíricos (doença, envelhecimento, falhas cognitivas contínuas, inércia da miséria moral ao longo da história), isto é, sem lançarmos mão de recursos desviantes? Na maioria das vezes, Pascal parece dizer que não há como escapar dessa dinâmica do desespero sem a intervenção de Deus. Essa temática é a fenomenologia da conversão, que ele trata nas suas correspondências espirituais, e que deságua numa reflexão acerca do déchirement (dilaceramento), e que fala do afastamento do desejo humano do mundo das criaturas, experimentado como agonia que rasga interiormente a estrutura humana, amante da criatura. ${ }^{21} \mathrm{E}$ mais: em estado de déchirement, 
no nível dos afetos, não há uma substituição da angústia por delírios de prazer. Pascal parece pensar que do ponto de vista estritamente humano restaria unicamente o enfrentamento da angústia que se instala quando o movimento desviante cessa: suspensão de mecanismos de auto-ilusão, haveria assim algum oxigênio para a negatividade em termos estritamente humanos. Isto é, o humano que não mente é, necessariamente, um melancólico. De qualquer modo, uma oração à perfectibilidade seria uma mentira diante dessa condição profunda experimentada por qualquer ser humano quando se dobra sobre si mesmo e apreende seu nada ontológico. Estamos diante de uma definição mínima: a insustentabilidade estrutural tornada consciente.

\section{Imaginação}

É essa parte dominante no homem, essa senhora de erro e falsidade, tão velhaca que nem sempre o é, pois ela seria regra infalível da verdade se o fosse da mentira. Ainda - mas sendo o mais freqüentemente falsa, ela não dá qualquer sinal de sua qualidade, marcando com o mesmo caráter o verdadeiro e o falso. Eu não falo dos loucos, eu falo dos mais sábios, e é entre eles que a imaginação tem o grande direito de persuadir os homens. A razão pode muito bem gritar, mas ainda assim ela não consegue dar o valor às coisas. (Cf. La 44)

Trata-se da clássica temática pascaliana de como a razão produz infelicidade enquanto a imaginação é a senhora da alegria. A amplitude da crítica aqui toca a epistemologia, que não é nosso foco no presente ensaio. A faculdade que marca tudo com o mesmo sinal, isto é, a contingência da adesão imaginada, dissolve todos os critérios. Sua ação perversa é maior entre os "sábios" na medida em que o orgulho intelectual aí é maior, o que tende inexoravelmente à diminuição da atividade epistêmica do indivíduo - a tendência agostiniana de fazer da moral um transcendental epistêmico é evidente em Pascal. A desarticulação promovida pela imaginação faz da oração à perfectibilidade um ato ridículo, na medida em que o Homem jamais sabe o que pensa que sabe - seja esse saber do campo estritamente cognitivo, seja do campo moral-valorativo. A afirmação final é excepcionalmente cética com relação ao alcance humano: resta o grito inútil.

Nos Lafuma 308 e 933, famosos fragmentos nos quais Pascal retoma a temática agostiniana das três concupiscências (matéria/corpo, espírito/ conhecimento, vontade/orgulho/caritas ou Deus) para fazer delas três ordens ontológicas gerais, vemos um aprofundamento de viés ontológico estrutural da dignidade ridícula. Nas palavras do scholar pascaliano Jean-Luc Marion, comentando esses fragmentos: 
(...) mas sobretudo estabelece que ele não os reúne senão para separá-los (disjoindre); na realidade, longe de constituir um sistema (...) aqui, na retomada pascaliana, uma "distância" os separa definitivamente. (...) infinito significa aqui a incomensurabilidade; "a distância infinita" (...) abole de uma só vez toda relação comensurável, dir-se-ia toda ordenação (...); nem ordo, nem mesura asseguram uma seqüência sistematizada. (Cf. Marion, 1986, p. 327)

Marion fala da relação que Pascal estabelece entre os elementos da metafísica cartesiana e as ordens pascalianas. Sua intenção é mostrar que os sinais de sustentação de um sistema metafísico organizador do mundo são despedaçados pela disjunção cósmica pascaliana - esse é o sentido do "enlouquecimento" dos conceitos que fala Marion na mesma obra. O Homem bem como o cosmos não compõem a idéia de natureza mínima, logo não são fundados metafisicamente. O alcance dessa metafísica negativa fere a dignidade imaginada na mesma medida em que o universo é definido pela indefinição, logo, louco: uma distância heterogênea infinitamente infinita produz abismos onde deveria haver sistema. O infinito é signo não de potência interminável (indefinida como na Oração de Pico), mas de exílio no nada da estrutura. Trata-se de um infinito negativo: não há hierarquias nem propriedades fixas, só espaços infinitos e vazios de quaisquer relações sustentáveis.

\section{Resto}

Aos olhos de nossos críticos do humanismo da perfectibilidade, a construção da oração ridícula não é somente fruto de uma decisão consciente do pecador, é muito mais (em termos filosóficos e teológicos) o resto de um sonambulismo da mecânica disjuntiva do Homem, exilado da sua causa fundante, afogado na contingência interna, asfixiado num coração que mente o tempo todo, um animal do medo. A dignidade nunca pode ser fundada por um ser que em si é sem fundamento, como uma sombra que tenta agarrar a si mesma. $\mathrm{O}$ pensamento da dignidade não instaura dignidade. $\mathrm{O}$ Homem não funda valor: esta sim é uma experiência humana, fruto de uma pesquisa elucidativa razoável. Talvez, nós, pós-modernos, possamos experimentar melhor do que os renascentistas essa consciência negativa da oração risível. Não me parece estranho o fato que tardiamente a oração esteja cada vez mais próxima (e necessitada) de uma retórica publicitária. 


\section{Referências Bibliográficas}

BARTH, K. Dogmatique IV. Cahier Genève, n. 1. [s.n.t].

CAMPANA, A. The Origin of the Word Humanist. [s.1.]: J. Warburg, 1946, p. 60-73.

CASSIRER, E.; KRISTELLER, P. O.; RANDALL JR, J. H. (Org.). The Renaissance Philosophy of Man. Chicago: The University of Chicago Press, 1956.

DREHER. Introdução a Da vontade cativa de Martin Lutero. In: . Obras selecionadas, debates e controvérsias.

ESPRIT, J. La Fausseté des vertus humaines. Paris: Aubier, 1996.

FAYE, E. Philosophie et perfection le l'homme. Paris: J. Vrin, 1998.

GOUHIER, H. L'Anti-humanisme au XVII ${ }^{\text {eme }}$ siècle. Paris: J. Vrin, 1987.

GUTTMANN, J. A filosofia do judaísmo. São Paulo: Perspectiva, 2003.

HESCHEL, A. I. Go in Search of Man. New York: FSG, 1999.

KAFKA, F. A construção. In: . Um artista da fome/A construção. São Paulo:

Cia. das Letras, 1998.

KRISTELLER. Introduction to Oration on the Dignity of Man. In: CASSIRER, E.; KRISTELLER, P. O.; RANDALL JR, J. H. (Org.). The Renaissance Philosophy of Man. Chicago: The University of Chicago Press, 1956.

LUTERO, M. Comentaire de l'épitre aux Galates. Genève: Labor et Fides, 1958.

. Da vontade cativa. In: Obras selecionadas, debates e controvérsias II. Porto

Alegre: Editora Sinodal/Concórdia Editora, 1993.

. Preface to Solomon's Ecclesiastes. In: THORNTON, J. F.; VARENNE, S. B.

(Org.). Faith and Freedom: An Invitation to the Writings of Martin Luther. New York:

Vintage Spiritual Classics/Random House, 2002.

. Preface to the Epistle of St. Paul to the Romans. In: THORNTON, J. F.;

VARENNE, S. B. (Org.) Faith and Freedom: An Invitation to the Writings of Martin Luther. New York: Vintage Spiritual Classics/Random House, 2002.

MARION, J. L. Sur le prisme métaphysique de Descartes. Paris: PUF, 1986.

MICHON, Hélène. L'ordre du cour, philosophie, théologie et mystique dan les Pensées de Pascal. Paris: Honoré Champion, 1996.

MIRÂNDOLA. Pico de La. Oration on the Dignity of Man. In: CASSIRER, E.; KRISTELlER, P. O.; RANDALL JR, J. H. (Org.) The Renaissance Philosophy of Man. Chicago: The University of Chicago Press, 1956.

PASCAL, B. Écrits sur la grace. In: MESNARD, Jean (Ed.). Euvres Complètes. Paris: DDB, 1991. Pensées. Paris: Intégrale/Seuil, 1963. (Ed. Lafuma)

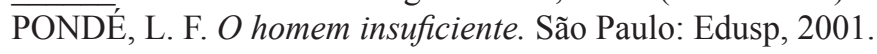
. Conhecimento na desgraça. São Paulo: Edusp. (No prelo)

QUIGNARD, P. Traité sur Esprit. In: ESPRIT, J. La Fausseté des vertus humaines. Paris: Aubier, 1996.

REHFELD, W. Nas sendas do judaísmo. São Paulo: Perspectiva, 2003.

RENAUDET, A. Autour d'une définition de l'humanisme. Biblioethèque Française de l'Humanisme, Travaux T VI, 1945. 
SELLIER, P. Pascal et Saint Augustin. Paris: Albin Michel, 1995.

SANTO AGOSTINHO. De natura et gratia. In: . La Crise Pélagienne. Paris:

IEA, 1994. v. I.

. Epistula ad hilarium syracusanum. In: . La Crise Pélagienne. Paris: IEA, 1994. v. I. 